\title{
INTEGRATED APPROACH TO ASSESSING THE SEISMIC HAZARD OF URBAN AREAS IN SOUTHERN PRIANGARIE (CASE OF THE LEFT BANK OF THE ANGARA RIVER IN IRKUTSK)
}

\author{
A. Yu. Eskin, V. I. Dzhurik, S. P. Serebrennikov, E. V. Bryzhak \\ Institute of the Earth's Crust, Siberian Branch of RAS, Irkutsk, Russia
}

\begin{abstract}
Seismic hazard assessment with the use of an integrated approach is discussed on the case of the left bank of the Angara river in Irkutsk, Russia. Potential earthquake focal zones have been identified in the study area. A brief overview of fault tectonics, seismology and seismogeology of the study area is presented. The map of the epicenters of local earthquakes and the map of active faults in the study area show the magnitudes of potential seismic events in the potential earthquake focal zones. The methodology of instrumental measurements and the methods of seismic hazard assessment are considered in detail. Calculations are based on the data obtained by the instrumental methods of seismic microzoning. Theoretical seismic effects on typical ground conditions are calculated, and the estimations are obtained with reference to maximum accelerations for predicted strong earthquakes. Estimated are potential seismic effects of probable strong earthquakes on the foundations of structures in the study area. Based on the estimations, an initial signal is formed (taking into account the potential earthquake focal zones, their parameters and the spectral composition of vibrations corresponding to the local earthquakes), and a required set of seismic models is developed in order to quantify the parameters of soil motions that may take place in the event of a strong earthquake. The experimental methods provided the data on the seismic properties of the reference and investigated soils, the propagation rates of seismic waves in such soils, and the pattern of microseism levels, as required for a valid estimation of seismic effect parameters by the seismic rigidity method and the microseism technique. Currently, both methods are by far the most effective in determining the seismic hazard of the territories. Statistical analysis was carried out using the calculations and the simulation data to more clearly determine the scatter of the results obtained. The seismic hazard of the study area is assessed based on the results of this study.
\end{abstract}

Key words: seismic model; accelerogram; seismic rigidity; maximum acceleration; seismic hazard; initial signal; resonant frequency

\section{RESEARCH ARTICLE}

Received: September 7, 2017

Handling Editor: V.S. Imaev

For citation: Eskin A.Yu., Dzhurik V.I., Serebrennikov S.P., Bryzhak E.V., 2018. Integrated approach to assessing the seismic hazard of urban areas in Southern Priangarie (case of the left bank of the Angara river in Irkutsk). Geodynamics \& Tectonophysics 9 (2), 515-530. doi:10.5800/GT-2018-9-2-0359.

Для цитирования: Ескин А.Ю., Джурик В.И., Серебренников С.П., Брыжак Е.В. Комплексный подход к оценке сейсмической опасности городских территорий в Южном Приангарье (на примере левобережья р. Ангары в г. Иркутске) // Геодинамика и тектонофизика. 2018. Т. 9. № 2. С. 515-530. doi:10.5800/GT-2018-9-2-0359. 


\title{
КОМПЛЕКСНЫЙ ПОДХОД К ОЦЕНКЕ СЕЙСМИЧЕСКОЙ ОПАСНОСТИ ГОРОДСКИХ ТЕРРИТОРИЙ В ЮЖНОМ ПРИАНГАРЬЕ (НА ПРИМЕРЕ ЛЕВОБЕРЕЖЬЯ Р. АНГАРЫ В Г. ИРКУТСКЕ)
}

\author{
А. Ю. Ескин, В. И. Джурик, С. П. Серебренников, Е. В. Брыжак
}

\author{
Институт земной коры СО РАН, Иркутск, Россия
}

\begin{abstract}
Аннотация: Рассмотрен комплексный подход к оценке сейсмической опасности грунтов представленных на участке, расположенном на левом берегу р. Ангары в черте г. Иркутска. Установлены зоны возможных очагов землетрясений (B03). Проведен краткий анализ материалов по разломной тектонике, сейсмологии и сейсмогеологии района исследования. Представлена карта эпицентров местных землетрясений и карта активных разломов окрестностей исследуемой территории с ожидаемой магнитудой будущих вероятных землетрясений из зон ВОЗ. Подробно рассматривается методика проведения инструментальных измерений и методы оценки сейсмической опасности. Выполнены расчеты по данным, полученным инструментальными методами сейсмического микрорайонирования. Реализованы теоретические расчеты сейсмических воздействий для типовых грунтовых условий, и дана их оценка по максимальным ускорениям для прогнозируемых сильных землетрясений. Расчетными методами выполнен прогноз сейсмических воздействий вероятных сильных землетрясений на основания сооружений. При использовании расчетных методов сформирован исходный сигнал (с учетом зон В03, их параметров и соответствующего местным землетрясениям спектрального состава колебаний), построено необходимое число сейсмических моделей, позволивших количественно оценить параметры движений грунта на случай сильных землетрясений. С использованием экспериментальных методов получены данные о сейсмических свойствах эталонных и исследуемых грунтов, скоростях распространения в них сейсмических волн и распределении уровней микросейсм, которые необходимы для обоснованной оценки параметров сейсмических воздействий по методу сейсмических жесткостей и методу микросейсм. Оба метода на сегодняшний день являются наиболее эффективными при определении сейсмической опасности территорий. Произведен статистический анализ по расчетным и экспериментальным методам для уточнения разброса полученных результатов. По результатам проведенных работ определена сейсмическая опасность исследуемой площади.
\end{abstract}

Ключевые слова: сейсмическая модель; акселерограмма; сейсмическая жесткость; максимальное ускорение; сейсмическая опасность; исходный сигнал; резонансная частота

\section{1. ВВЕДЕНИЕ}

В пределах юго-западной части Сибирской платформы вдоль р. Ангары расположен ряд крупных промышленных центров - Иркутск, Ангарск, Усолье-Сибирское и др. В связи с тем, что в настоящее время идет интенсивное развитие этих городов и освоение прилегающих к ним территорий, а также с учетом того, что Южное Приангарье - это сейсмически активная область, при строительстве зданий и сооружений требуется оценка сейсмической опасности региона, особенно при освоении береговой зоны. Исходя из того, что во многих городах, расположенных вдоль р. Ангары, для береговой зоны характерны сходные грунтовые условия, одни и те же зоны возникновения очагов землетрясений (В03), их параметры целесообразно рассмотреть на конкретном примере комплексного подхода к оценке сейсмической опасности аналогичных территорий. Для этого были проведены работы по микрорайонированию площадки на левом берегу р. Ангары в пределах г. Иркутска. Данный участок выбран неслучайно. Береговая зона в черте г. Иркутска быстро застраивается высотными домами, и оценка сейсмической опасности данной территории является крайне важной.

\section{2. СЕЙСМОТЕКТОНИКА, СЕЙСМИЧНОСТЬ И ИНЖЕНЕРНО- ГЕОЛОГИЧЕСКИЕ УСЛОВИЯ РАЙОНА ИССЛЕДОВАНИЯ}

Территория исследования расположена на левом берегу р. Ангары в пределах г. Иркутска, который, в свою очередь, находится в юго-западной части активизированной окраины Сибирской платформы, где основным разрывным нарушением, ответственным за высокий сейсмический потенциал территории, является Главный Саянский разлом [Golenetsky, 1997]. При относительно высокой сейсмической активности в пределах активной части 


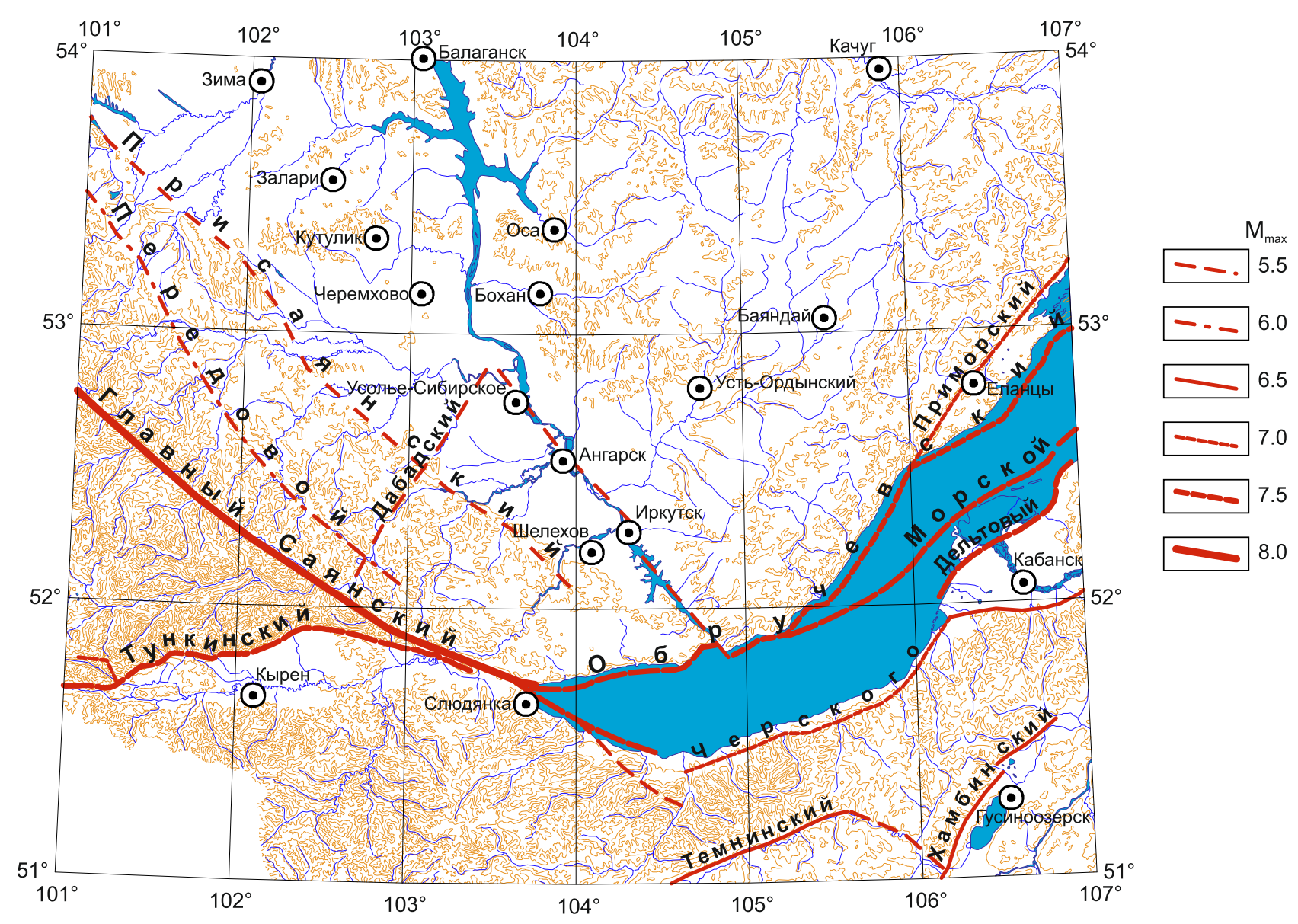

Рис. 1. Карта-схема очагов землетрясений (зон В03) региона.

Fig. 1. Regional schematic map of earthquake foci (showing the seismic source zones).

разлома выявлены палеосейсмогенные структуры с возможной магнитудой сейсмических событий до 8.0 (рис. 1). Главный Саянский разлом является основой Восточно-Саянской зоны ВОЗ с магнитудой 8.0 [Logachev, 1996].

Другим наиболее крупным в регионе разрывным нарушением является Приморский разлом (рис. 1). Высокую сейсмическую активность разлома, по крайней мере в недавнем прошлом, подтверждают присутствующие здесь палеосейсмогенные структуры. Приморскому разлому соответствует одноименная зона ВОЗ с возможной магнитудой до 7.5.

Расположенный в непосредственной близости от исследуемого участка Ангарский разлом протягивается от оз. Байкал вдоль долины р. Ангары на расстояние более 150 км при ширине зоны разрыва до 15 м. Разлом представляет собой зоны повышенной трещиноватости в плейстоцен-голоценовых отложениях песчано-глинистого и песчаногалечного состава.

Другой формой представления уровня сейсмичности является карта эпицентров землетрясений региона (рис. 2) [Levi, Masalsky, 2005].
Из карты эпицентров землетрясений территории (рис. 2) видно, что ближние сейсмически активные зоны расположены к югу от изучаемого участка. Основные области возникновения землетрясений приурочены к акватории южной и средней части оз. Байкал и системе Тункинских впадин. Уровень сейсмической опасности территории в большей степени определяется расположением зон В03 с возможным проявлением сейсмичности магнитудой 6-7 и более. Таким образом, анализ макросейсмических данных о сейсмических событиях в пределах г. Иркутска (исторический и инструментальный периоды) и расчетные данные о возможном транзитном сейсмическом сотрясении из расположенных на исследуемой площади зон ВОЗ позволяют сделать вывод: участок четвертой Ангарской террасы находится в зоне возможной интенсивности сотрясений 8 баллов [The Мap..., 1999].

Для проведения сейсмического микрорайонирования изучаемой территории использовались материалы инженерно-геологических изысканий, выполненных на данном участке.

Инженерно-геологический комплекс площади исследования представлен делювиальными и ал- 


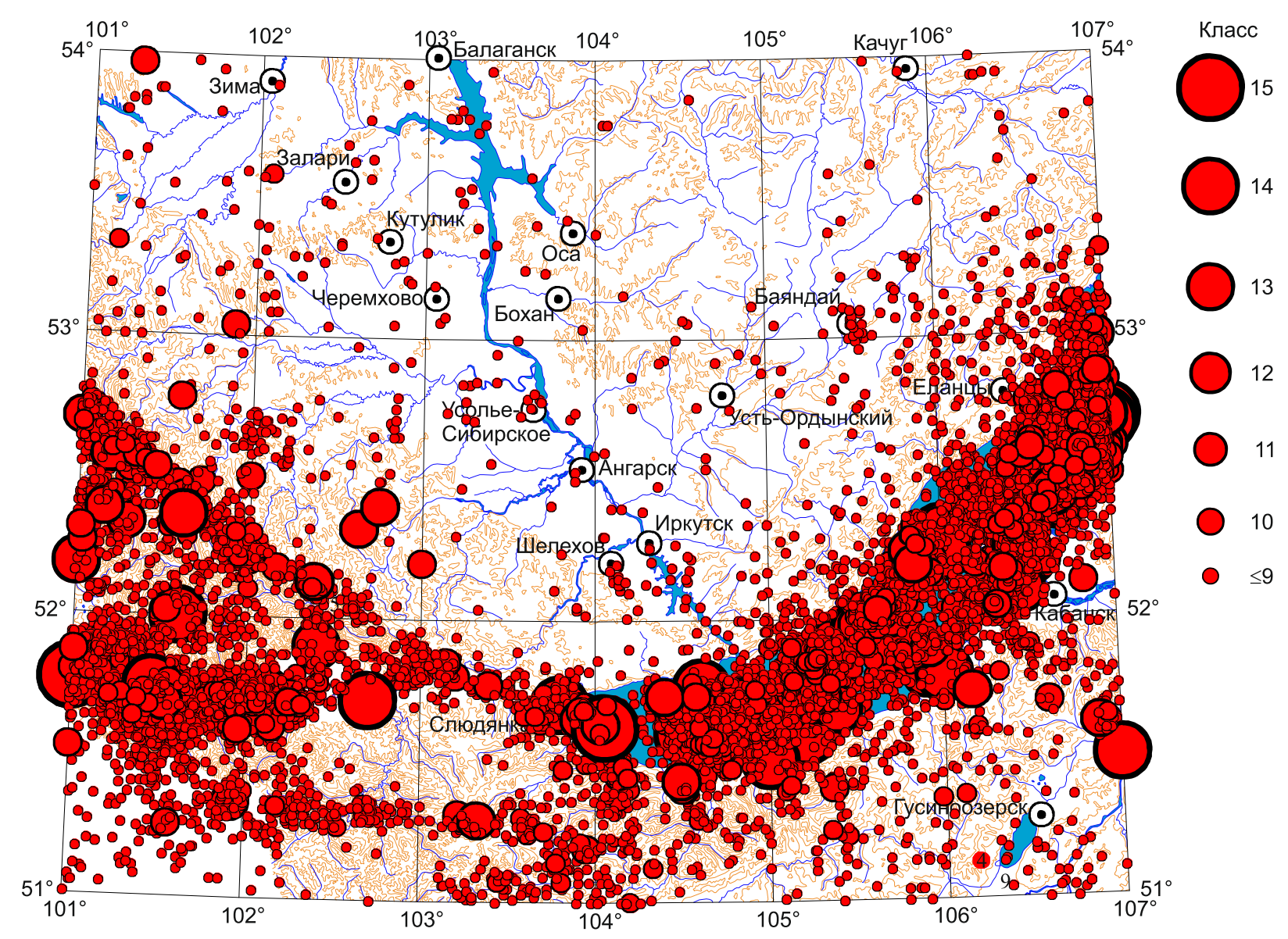

| Рис. 2. Карта эпицентров зарегистрированных землетрясений региона.

I Fig. 2. Map of earthquake epicenters recorded in the study region.

лювиальными отложениями четвертичного возраста. В состав делювиальных отложений входят суглинки (мощностью до $11 \mathrm{M}$ ) и глины (мощностью до $2.4 \mathrm{M}$ ), пески (мощность слоев до $4.5 \mathrm{M}$ ), щебень, дресва (мощностью до 2.1 м). Основу аллювиальных отложений составляет галечниковый грунт с глубины 8.4 м, мощность слоев до 2 м, и пески. Галечниковый грунт перекрыт песками мощностью до 1 м или замещен ими.

Суммарная мощность четвертичных рыхлых образований в пределах рассматриваемой площади колеблется от 9 до 12 м (с поверхности 12-18 м). Отложения перекрыты насыпными грунтами мощностью до 4 м.

По данным бурения до глубины 30 м, скальные образования вскрыты с поверхности 12-14 м и представлены песчаниками с различной степенью трещиноватости, с включением слоев песчанистого суглинка. На исследуемой площади находится горизонт грунтовых вод в четвертичных грунтах аллювиального происхождения в интервале 7.0-9.5 м от поверхности, водоупорный слой представлен глинами, скальными грунтами (установившаяся мощность водоносного горизонта до 4 м).
Исходные материалы для определения сейсмической опасности были получены путем постановки сейсморазведочных, сейсмометрических (регистрация микросейсм) и электроразведочных измерений (рис. 3) [Pavlov, 1988; RSN 65-87, 1987]. Для оценки основных параметров сейсмических воздействий использовался метод сейсмических жесткостей, метод микросейсм и расчетные методы [Medvedev, 1962; RSN 65-87, 1987; Calculation methods..., 1998].

\section{3. КОМПЛЕКСНАЯ ОЦЕНКА СЕЙСМИЧЕСКОЙ ОПАСНОСТИ ОБЪЕКТА ИССЛЕДОВАНИЙ}

Сейсморазведочные измерения. Сейсморазведочные работы методом преломленных волн проводились с использованием 24-канальной компьютеризированной цифровой станции «Лакколит» (Россия). Измерения проводились отдельными зондированиями с обеспечением встречных и нагоняющих годографов. Длина годографов, ввиду наличия большого фона промышленных, транспортных и электрических помех, составляла 46 м, 


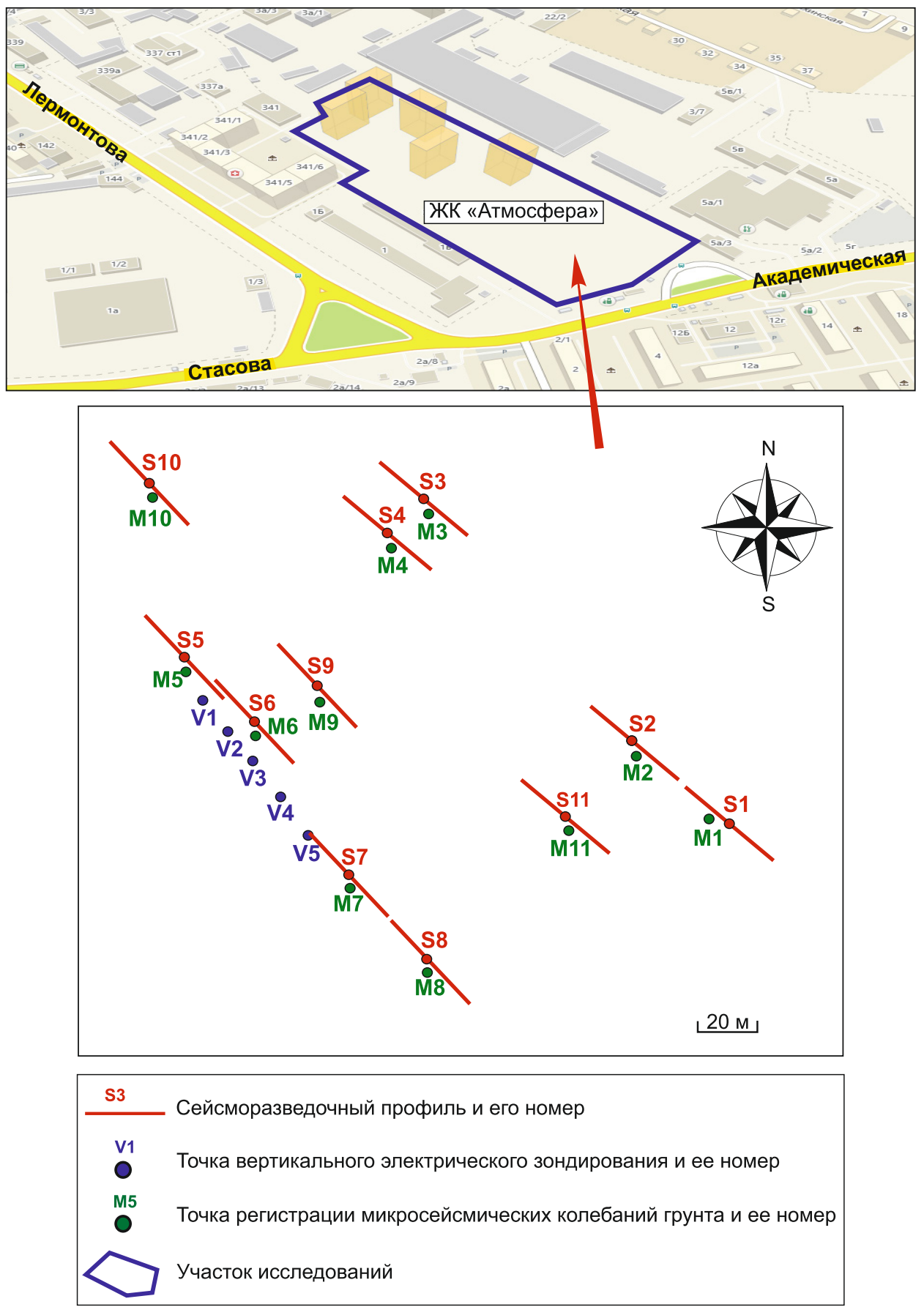

Рис. 3. Схема работ на площади исследования, г. Иркутск.

Fig. 3. Scheme of works on the study area (Irkutsk, Russia).

по возможности с обеспечением нагоняющих годографов. Сейсмические волны возбуждались с помощью ударов $[R S N$ 66-87, 1987]. Привязка на местности осуществлялась по GPS-геодезии и с помощью мерной ленты. Точки измерений наносились на топооснову в соответствующем масштабе. Наблюдения проводились с возможностью регистрации продольных и поперечных волн. Такая методика измерений позволяет получать средние значения скоростей в верхней зоне разреза до глуби- ны 10-20 м. Скорости сейсмических волн в коренных (эталонных) породах измерялись в районе г. Иркутска в карьерах и на выходах коренных пород (при неглубоком залегании), использовались и полученные ранее данные для территории г. Иркутска. Обработка сейсмограмм проводилась при использовании программы RadExPro.

Общая схема инструментальных измерений показана на рис. 3. Она характеризует их плотность, распределение по площади и привязку на местно- 
сти. Всего по изложенной выше методике выполнено 11 сейсмозондирований непосредственно на изучаемой площади и 5 - для изучения «эталонных» грунтов в районе г. Иркутска.

Регистрация микросейсм. При проведении сейсмического микрорайонирования (СМР) в комплексе с методом сейсмических жесткостей применялся метод «микросейсм» [Seismic Microzoning Guidelines, 1988]. В основе метода лежат измерения смещений грунта и анализ реакции различных категорий грунтов на микросейсмические колебания естественного или техногенного происхождения [Gorbatikov et al., 2008]. Измерения уровня и спектральный анализ микросейсмических колебаний позволяют оценить сейсмические свойства грунта на исследуемом участке по амплитудно-частотным характеристикам (АЧХ) и тем самым определить их резонансные и сейсмические характеристики [Pavlov, 1984].

В результате рассчитывались частотные характеристики (АЧХ) методом спектральных отношений. Для этого проводился спектральный анализ микросейсм, а АЧХ определялись по отношению между спектрами горизонтальных и вертикальных компонент. Этот способ позволяет компенсировать спектральные компоненты, вызываемые техногенным шумом, и получить достаточно надежные оценки преобладающих периодов (частот) колебаний грунтов.

В этом случае амплитудно-частотная характеристика определяется согласно выражению:

$$
\mathrm{U}(\mathrm{x})=\left(\mathrm{H}_{\mathrm{N}}+\mathrm{H}_{\mathrm{E}}\right) /\left(2 \mathrm{~V}_{\mathrm{Z}}\right)
$$

где $\mathrm{H}_{\mathrm{N}}, \mathrm{H}_{\mathrm{E}}$ - спектры микросейсм по горизонтальным компонентам «NS» и «EW», $\mathrm{V}_{Z}$ - спектр по вертикальной компоненте «Z».

Максимальное значение АЧХ связано с резонансными особенностями рыхлой толщи грунта и определяет его сейсмические свойства. Приращения балльности определяются по формуле:

$$
\Delta \mathrm{I}=\mathrm{KlgU}_{\max }
$$

где $\mathrm{K}$ - эмпирический коэффициент, $\mathrm{U}_{\max }$ - максимальные значения АЧХ. Приращения балльности определяются относительно скального грунта.

Для записи микроколебаний на участке использовалась многоканальная цифровая сейсмическая станция Байкал 7HR с трехкомпонентными сейсмоприемниками СК-1П. Применяемая аппаратура обеспечивала динамический диапазон 96 дБ в полосе частот от 0.1 до 300 Гц, в режиме регистрации скорости перемещений. В каждом пункте измерения для получения необходимой статистической надежности в оценке уровня и спектрального со- става микроколебаний регистрация велась не менее 15 минут. При этом регистрировались колебания горизонтальной плоскости в двух направлениях - X и Y, ориентированных на север и восток, и в вертикальной плоскости в направлении Z. Измерениями микросейсм так же равномерно покрыта исследуемая площадь, а пункты измерений привязаны к сейсмозондированиям (рис. 3). В каждом пункте измерения проводились двумя комплектами приборов, что повышало достоверность регистрации микросейсм.

Электроразведочные измерения методом вертикальных электрических зондирований (BЭ3). Постановка электроразведки на микрорайонируемой площади обоснована необходимостью дополнить данные о строении верхней зоны разреза возможностью определения глубины залегания «эталонных» коренных пород с целью их дальнейшего использования при реализации расчетных методов.

Измерения электрических сопротивлений выполнялись методом ВЭЗ по стандартным методикам [Electrical Exploration..., 1982] с помощью цифровой электроразведочной аппаратуры «Электротест-С» (Россия). На участке исследований было выполнено пять ВЭЗ симметричной установкой AMNB с разносами $\mathrm{AB} / 2$ до 150 м (рис. 3), что при благоприятных геоэлектрических условиях дает возможность изучать распределение электрических сопротивлений на глубину до 60 м и более.

Экспериментальный материал (кривые ВЭЗ), полученный с учетом фона электрических помех и застройки территории, можно считать удовлетворительным (в отношении его интерпретации). В основном это кривые типа QHКН, выход на Н намечается, что свидетельствует о возможном залегании опорного горизонта - коренных пород. Точность измерений определена как $5 \%$, не более. Привязка на местности осуществлялась с помощью GPS-геодезии и мерной ленты. Интерпретация кривых проводилась по программе IPI2Win [IPI2Win User Guide, 2001].

Результаты интерпретации построенных кривых ВЭЗ представляются в виде геоэлектрического разреза (рис. 4). Сам геоэлектрический разрез сверху, до 2-3 м, характеризуется относительно повышенным значением удельного электрического сопротивления (УЭС) около 100-500 Ом·м. Это может быть связано с началом промерзания (ноябрь) или пониженной влажностью рыхлых грунтов. Ниже идет слой 4-6 м, имеющий пониженное сопротивление (14 Ом·м), он представлен в основном суглинками и глиной. До глубины 18-20 м УЭС увеличивается до 50 Ом·м (галечниковый грунт) и далее до глубины 40-43 м опять понижается до 


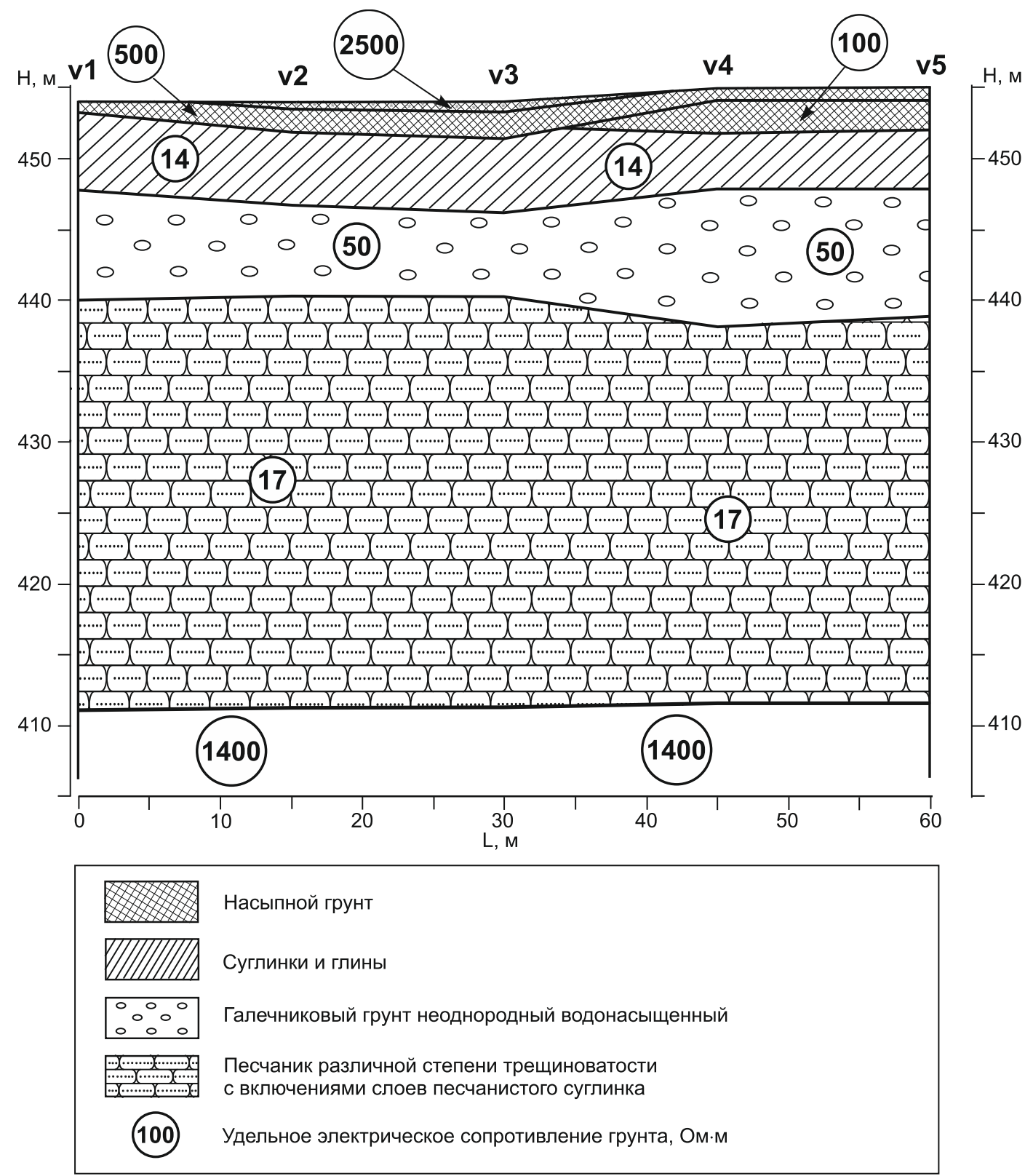

Рис. 4. Геоэлектрический разрез по створу кривых ВЭЗ № 1-5 (см. рис. 3).

Fig. 4. Geoelectric profile along the line between VES curves 1 and 5 (see Fig. 3).

17 Ом·м. Последний слой представлен песчаниками с различной степенью трещиноватости и включением слоев песчанистого суглинка.

Слой с повышенным сопротивлением с глубины более 40 м может быть отнесен к трещиноватым полускальным грунтам, с сопротивлением 1400 Ом·м. Дальнейшее повышение сопротивлений по конечной ветви кривых ВЭЗ в геоэлектрическом разрезе мы связываем с составом полускальных пород и уменьшением степени заполнения их трещин песчанистым суглинком и водой.

Данные интерпретации ВЭЗ в виде геоэлектрического разреза использовались при комплексной оценке сейсмической опасности участка исследо- вания и для построения расчетных сейсмических моделей.

Расчетные методы применялись для получения необходимых параметров сейсмических воздействий на случай сильных землетрясений: акселерограмм, спектров ускорений, максимальных ускорений и частотных характеристик рыхлой толщи [Calculation methods..., 1998; Seismic Microzoning Guidelines..., 1988; Dzhurik et al., 2016].

Ниже кратко излагаются полученные результаты полевых измерений и расчетов по каждому из использованных методов, которые приводят к возможности оценки сейсмической опасности исследуемого участка (см. рис. 3). 
(a)

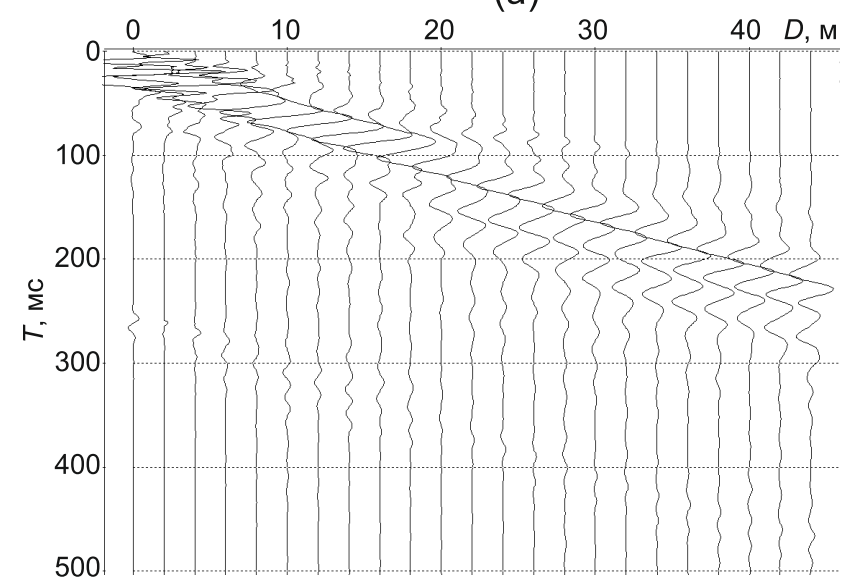

(в)

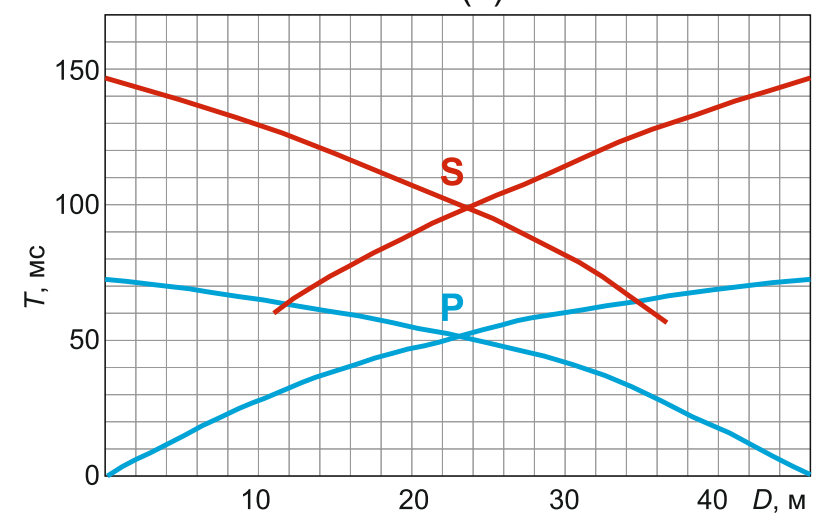

(б)

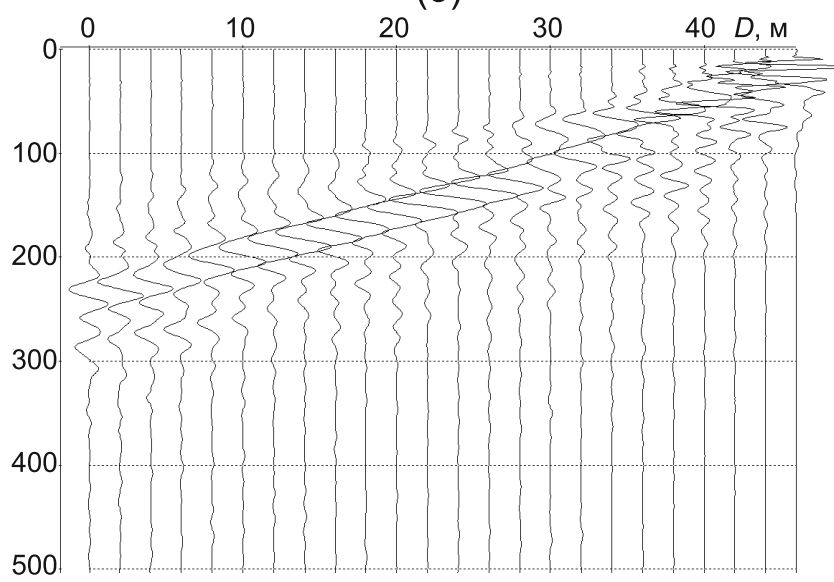

(2)

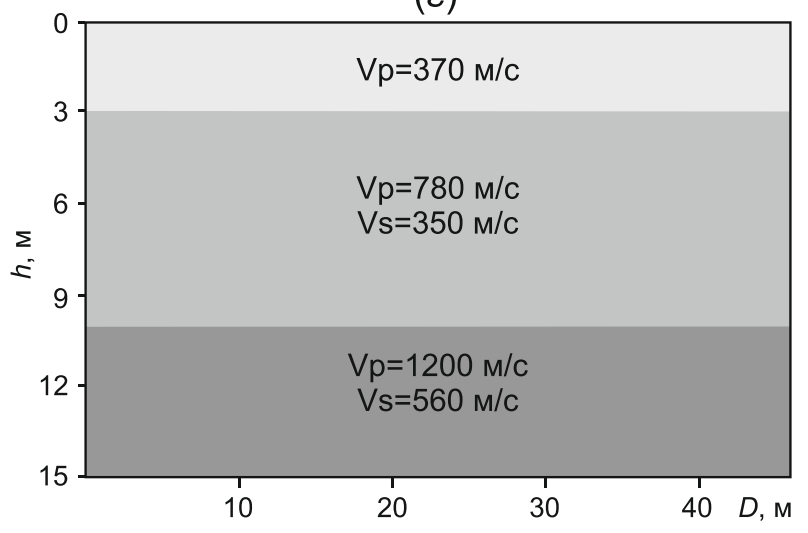

Рис. 5. Пример прямой $(a)$ и встречной (б) сейсмограмм, годографов продольных (P) и поперечных (S) волн $(\theta)$ и скоростного разреза (2) для пункта сейсмического зондирования S1 (см. рис. 3).

Fig. 5. Example: direct ( $a$ ) and reversed (б) seismograms, hodographs of longitudinal (P) and transverse (S) waves ( $(8)$, and velocity profile (2) for seismic sounding site S1 (see Fig. 3).

Метод сейсмических жесткостей. Для реализации расчетов по методу сейсмических жесткостей необходим выбор «эталонных» значений скоростей сейсмических волн в «коренных» и по возможности «средних» грунтах, отвечающих принятой исходной сейсмичности, равной 8 баллам.

Результаты измерения скоростей сейсмических волн, необходимые для расчетов сейсмической опасности по этому методу, представлены в виде примеров сейсмограмм, годографов и скоростных разрезов по пунктам зондирований на площади (рис. 5) и коренных пород в районе, максимально приближенном к участку исследования (рис. 6).

Практически повсеместно до глубины 18-20 м выделяются два или три слоя. Верхний слой сезонного промерзания (до 0.5 м на период измерений) и протаивания (до 2-3 м) имеет низкие значения скоростей Vp - от 360 до 460 м/с. Второй слой, мощностью от 4 до 6 м, имеет значительный диапазон изменения скоростей - от 660 до 800 м/c - Vp и от 310 до 380 м/c - Vs. Ниже этого слоя скорости продольных волн увеличиваются до 1010-1350 м/с - Vр и 450-600 м/с - Vs и могут соответствовать слою (до 7-9 м) водонасыщенному гравийногалечному с песчаным заполнителем грунтов. Верхнему горизонту разрушенных трещиноватых полускальных пород, начиная с глубины 18-20 м от поверхности, соответствует скорость 2060 м/с - Vp и $1040 \mathrm{~m} / \mathrm{c}-\mathrm{Vs}$.

Отмеченные значения скоростей в полускальных грунтах подтверждаются данными ультразвуковых измерений на 60 образцах пород, отобранных из скважин на территории исследуемой площади. Это распределение дает наиболее вероятные значения скоростей продольных волн в сильнотрещиноватых песчаниках от 1000 до 1800 м/с и в относительно сохранных при естественной влажности - от 2000 до 3200 м/с. Отмеченные значения скоростей учитывались при выборе эталона и составлении расчетных сейсмогрунтовых моделей. 
(a)

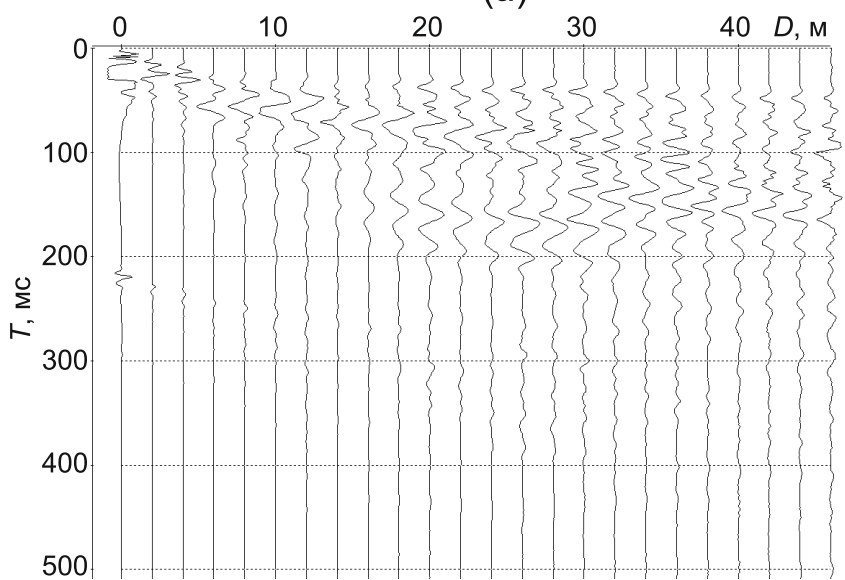

(8)

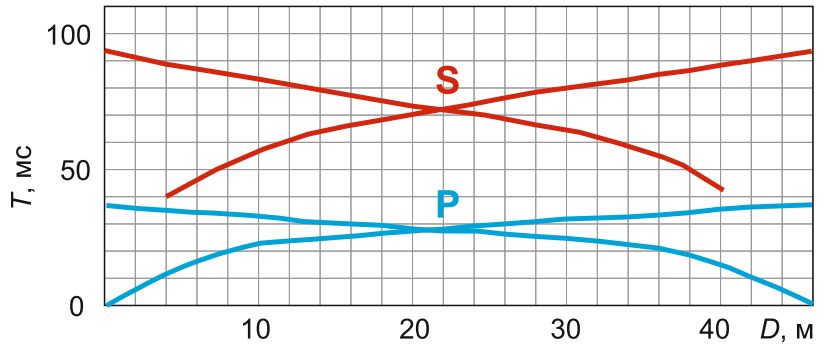

(б)

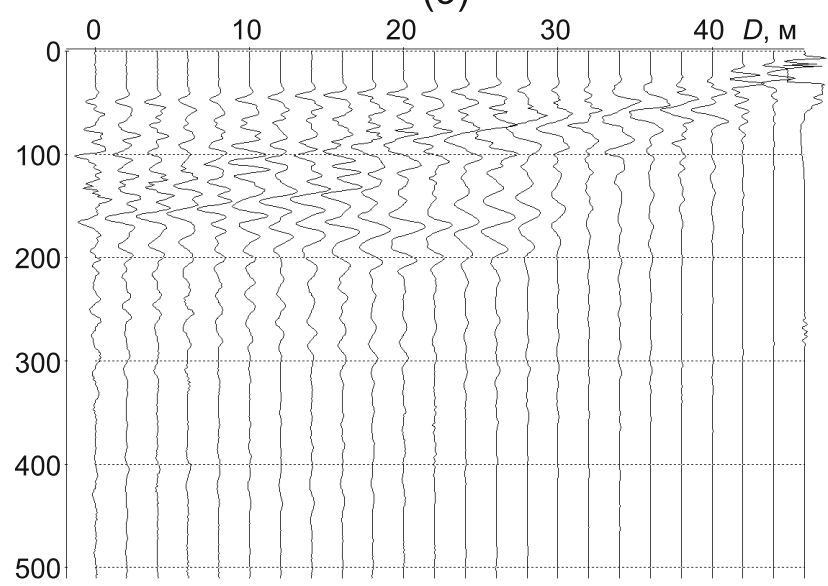

(2)

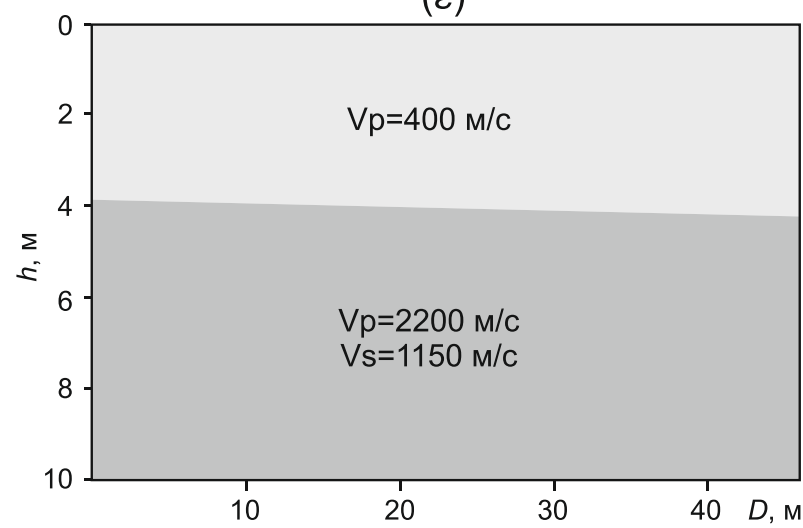

Рис. 6. Пример прямой $(a)$ и встречной (б) сейсмограмм, годографов продольных (P) и поперечных (S) волн (в) и скоростного разреза (2) на участке близкого залегания коренных пород в районе исследований.

Fig. 6. Example: direct (a) and reversed (б) seismograms, hodographs of longitudinal (P) and transverse (S) waves ( 8 ), and velocity profile (2) for the shallow bedrock site located in the study area.

На основе значений скоростей сейсмических волн в разрушенных трещиноватых скальных грунтах с учетом результатов выполненных ранее исследований на территории г. Иркутска [Dzhurik et al., 2016; Drennov et al., 2011] за эталон принимаются наиболее вероятные значения скоростей и плотность в трещиноватых коренных породах: $V p=2100$ м/с, Vs=1150 м/с, $\rho=2.4 \mathrm{r} / \mathrm{cm}^{3}$. Их сейсмическая опасность принимается равной 7 баллам.

По такой же схеме обработаны «средние» грунты, к ним отнесена неводонасыщенная толща рыхлых отложений мощностью не менее 10 м $[R S N$ 65-87, 1987]. Скорости сейсмических волн в них приняты равными 600 м/с - Vp, 300 м/c - Vs, и объемная масса 1.8 г/ $\mathrm{cm}^{3}$. Сейсмическая опасность «средних» грунтов принимается равной 8 баллам.

Скорости поперечных волн фиксируются из-за помех не всегда уверенно, поэтому они иногда определялись при использовании поверхностных волн и по ранее установленной зависимости
$\mathrm{Vp}=\mathrm{f}(\mathrm{Vs})$ с учетом состояния грунтов [Gurvich, Nomokonov, 1981].

Таким образом, для проведения расчетов сейсмической опасности по методу сейсмических жесткостей (МСЖ), построения необходимого набора сейсмических моделей и реализации расчетных методов получены все необходимые данные о составе грунтов, скоростях распространения в них сейсмических волн и объемной массе эталонных и исследуемых грунтов.

Для оценки сейсмической опасности по методу сейсмических жесткостей расчет приращений балльности проводился по формуле С.В. Медведева [Medvedev, 1962]:

$$
\Delta \mathrm{I}=1.67 \lg \left(\mathrm{p}_{\ni} \mathrm{V}_{\ni} / \mathrm{p}_{\mathrm{i}} \mathrm{V}_{\mathrm{i}}\right),
$$

где $\mathrm{p}_{\ni} \mathrm{V}_{\ni}$ и $\mathrm{p}_{\mathrm{i}} \mathrm{V}_{\mathrm{i}}$ - сейсмические жесткости эталонного и исследуемого грунта для продольных (Vp) или поперечных (Vs) волн, $\Delta \mathrm{I}$ - расчетные значения приращений балльности. 
Для рыхлых водонасыщенных грунтов к формуле (3) вводится поправка, учитывающая глубину залегания уровня грунтовых вод $(\mathrm{h})$, согласно выражению:

$$
\Delta \mathrm{I}_{\mathrm{yгв}}=\mathrm{R} \cdot e^{-0.04 h^{2}} .
$$

Коэффициент $\mathrm{R}$ для участков, где преобладают песчаные и глинистые грунты принимается равным 1, а где грубообломочные, гравийно-галечные - 0.5. При глубине залегания уровня грунтовых вод (УГВ) ниже 7-10 м от фундамента поправка $\Delta$ Іугв не вводится. В этом случае при расчетах приращений по формуле (3) скорости продольных волн для водонасыщенных слоев берутся для таких же по составу грунтов, но находящихся в воздушно-сухом состоянии.

Приращения балльности по отношению к эталонному грунту (коренные породы) по методу сейсмических жесткостей лежат в пределах от 0.92 до 1.04 балла по средним значениям Vр и от 1.01 до 1.13 балла по средним значениям Vs. Последние приведены для сравнения расчетов по данным средних значений скоростей для продольных и поперечных волн, и они достаточно хорошо согласуются в пределах погрешности расчетов по МСЖ. Но для построения карты сейсмомикрорайонирования участка использовались данные расчетов приращений по скоростям продольных волн, как определяемых более надежно.

Поправка за обводненность при залегании УГВ ниже 7 м может и не учитываться, как это было отмечено ранее, но и при расчетах не будет превышать 0.15 балла для рыхлых грунтов площади исследования на этих глубинах (согласно формуле (4)). Это отвечает гидрогеологическим условиям участка изучения и учтено при суммарной оценке приращений балльности по МСЖ $\left(\mathrm{J}^{*}=\mathrm{I}_{\text {исх }}+\Delta \mathrm{Ipv}+\right.$ $+\Delta \mathrm{I}$ угв). В итоге сейсмическая опасность участка исследований по методу сейсмических жесткостей оценивается в пределах 8.07-8.19 балла и принимается равной 8 баллам.

Метод микросейсм. Регистрация микросейсм по изложенной выше методике проводилась на территории участка четвертой Ангарской террасы согласно схеме (см. рис. 3). Пункты регистрации микросейсм располагались в центре сейсморазведочных профилей. Сами результаты наблюдений представлены в виде примера записей микросейсм для трех компонент (рис. 7).

Стоит отметить, что оценка сейсмической опасности и частотного состава колебаний для каждой точки проводилась непосредственно по максимуму частотной характеристики, согласно приведенным выше формулам и по относительным частотным характеристикам. Как мы видим, в пре-
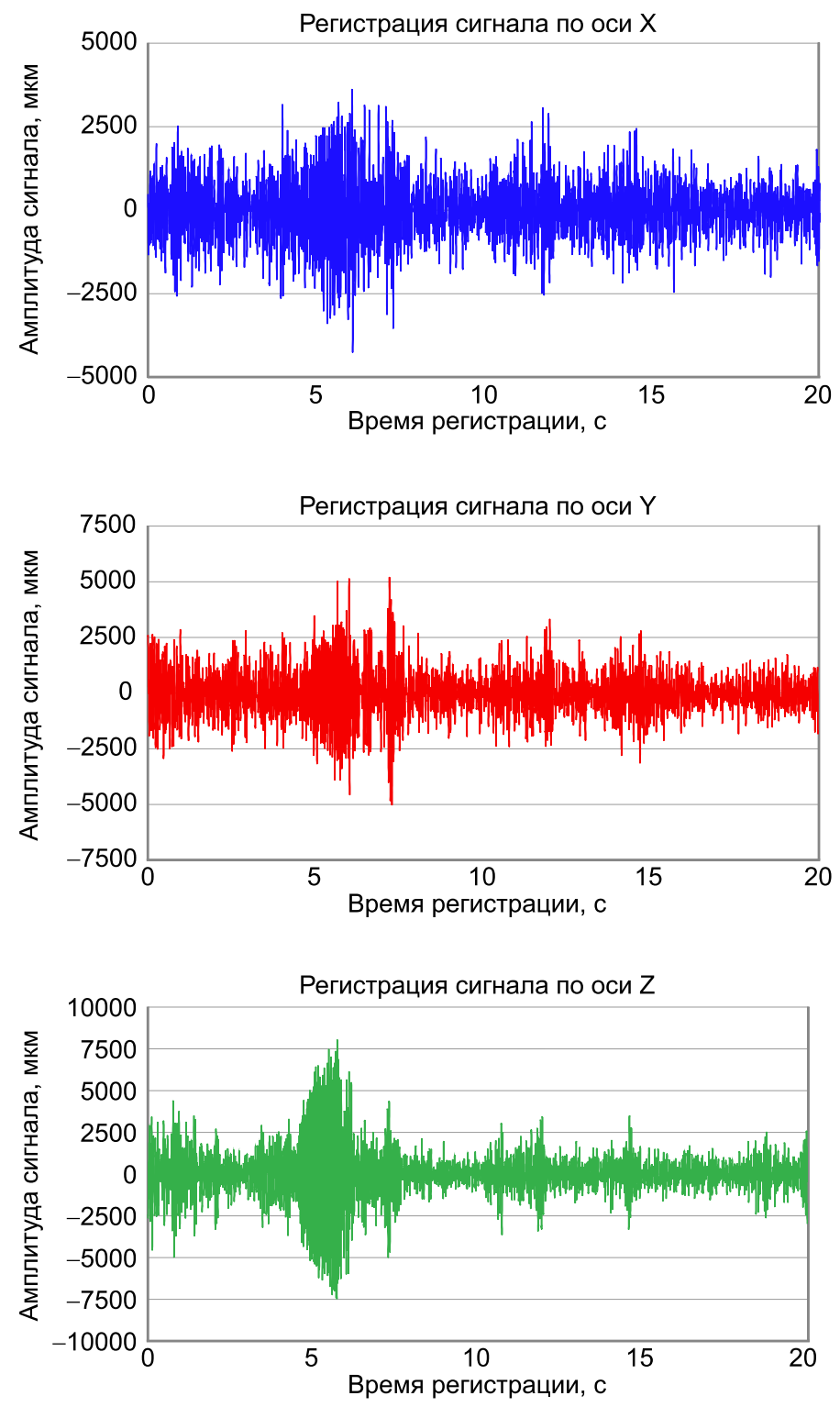

Рис. 7. Пример записи микросейсм в пункте наблюдения М2 (см. рис. 3).

Fig. 7. Example: microseism recorded on monitoring site M2 (see Fig. 3).

делах 0-20 Гц опасные для сооружения частоты приходятся на интервал от 4.6 до 10.5 Гц, а максимальные значения частотной характеристики (U(f)) на указанных частотах лежат в интервале 1.9-2.4.

Представленный достаточно большой набор экспериментальных данных по методу микросейсм и относительная однородность сейсмомикрорайонируемой территории по инженерно-геологическим и сейсморазведочным данным позволяет получить среднюю частотную характеристику (рис. 8). Осреднение проведено по значениям максимальных амплитуд на фиксированных частотах. 


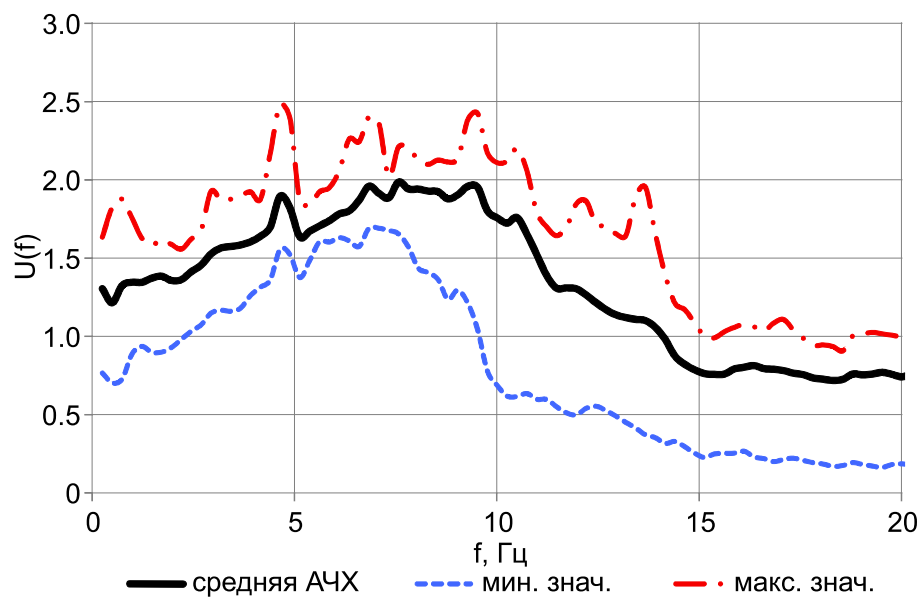

Рис. 8. Средние, максимальные и минимальные значения АЧХ.

Fig. 8. Frequency response: average, maximum and minimum values.

Основные максимумы средней частотной характеристики находятся в интервале 1.7-2.0 и приходятся на диапазон частот от 4 до 12 Гц. Для максимальной частотной характеристики в этом же диапазоне частот их максимумы находятся в интервале 1.9-2.4.

Уровни передаточных функций (АЧХ) непосредственно использовались для расчета приращений балльности для каждого пункта регистрации микросейсм. Коэффициент К в формуле (2) принимался равным 3.3, т.е. предполагалось, что частотные характеристики, полученные методом спектральных отношений, являются наиболее близкими к детерминированным, получаемым по данным записей землетрясений.

В результате по отношению к эталонным коренным породам приращения сейсмической опасности оцениваются в интервале от 0.91 до 1.30 балла, а сейсмическая опасность по этому методу меняется от 7.91 до 8.30 балла и принимается для площади исследований равной 8 баллам.

Первый способ расчета параметров сейсмических воздействий. Согласно нормативным документам [Building Code II-7-81*, 2011; RSN 65-87, 1987], результаты должны отражать оценку сейсмической опасности в основных параметрах сейсмических воздействий, необходимых для проектирования сейсмостойких сооружений, поэтому дальнейшей задачей является формирование исходного сигнала для района расположения изучаемой площади.

В конечном итоге для изучаемой территории сформирован исходный сигнал с учетом особенностей спектрального состава колебаний из каждой выбранной зоны ВОЗ (см. рис. 1, 2). Для этого спек- тры колебаний отобранных землетрясений были нормированы, затем они усреднялись, рассчитывалась фазовая характеристика одной из записей землетрясений и обратным преобразованием Фурье проведен расчет нормированной акселерограммы (рис. 9). Амплитудный спектр этого сигнала, в свою очередь, отражает все частотные особенности акселерограмм, которые спрогнозированы для отдельных зон В0З. Его уровень, превышающий значение 0.7 от максимального (0.7 Smax), лежит в интервале частот 0.97-5.22 Гц. Основной максимум приходится на частоту 2.88 Гц, спектральная плотность достигает значения $0.165 \mathrm{~cm} / \mathrm{c}$.

Таким образом, параметры синтезированной акселерограммы (по частотному составу) отвечают как близким, так и относительно далеким сильным землетрясениям, по частотному составу учтены основные особенности зон ВОЗ для исследуемой территории. Для обоснования максимальных значений ускорений нет достаточного количества записей сильных землетрясений из выделенных зон В03 (см. рис. 1, 2), поэтому было применено масштабирование сформированной акселерограммы, что не противоречит существующим нормативным документам.

Для того чтобы использовать исходный сейсмический сигнал в дальнейших теоретических расчетах для грунтовой модели участка, необходимо привести его к эталонному грунту. Выше приводится анализ скоростей сейсмических волн в коренных породах в районе г. Иркутска и в рыхлых
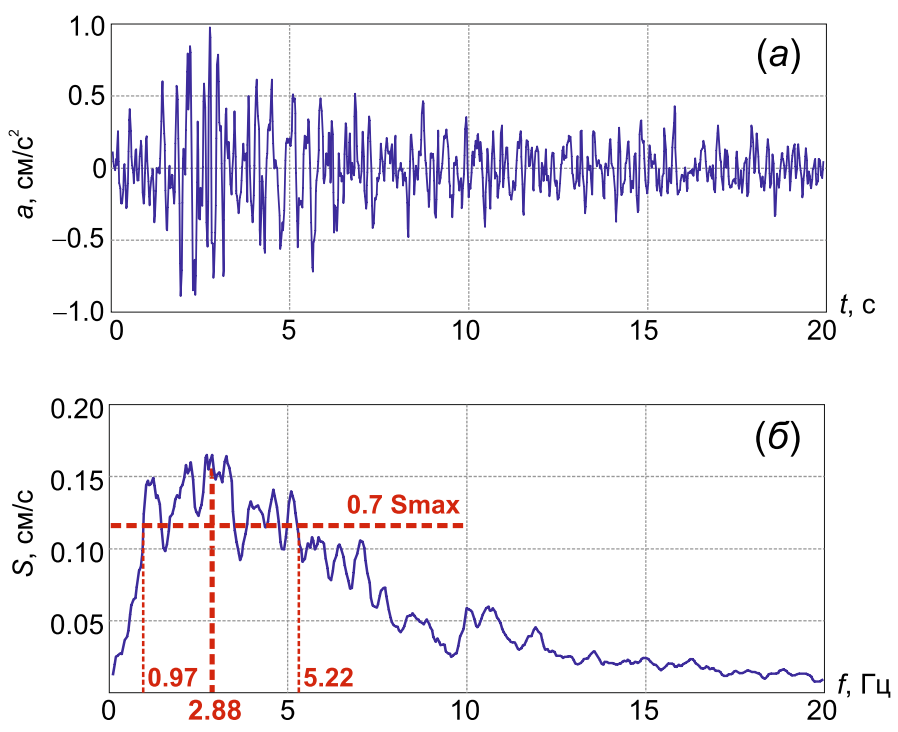

Рис. 9. Исходная нормированная акселерограмма $(a)$ и ее амплитудный спектр (б).

Fig. 9. Initial normalized accelerogram $(a)$ and its amplitude spectrum (б). 
A.Yu. Eskin et al.: Integrated approach to assessing the seismic hazard of urban areas...

Т а б л и ц а 1 . Основные параметры расчетных акселерограмм и соответствующих им спектров для моделей 1-3

$\mathrm{T}$ a b l e 1. Main parameters of calculated accelerograms and corresponding spectra for models 1, 2, and 3

\begin{tabular}{|c|c|c|c|c|c|}
\hline № модели & $\begin{array}{l}\text { Максимальное } \\
\text { ускорение } \\
\text { Ӓмах }\left(\mathrm{cm} / \mathrm{c}^{2}\right)\end{array}$ & $\begin{array}{l}\text { Максимальное } \\
\text { значение спектра } \\
\text { Smax (cм/c) }\end{array}$ & $\begin{array}{l}\text { Частота основного мак- } \\
\text { симума спектра } \\
(\text { Гц) }\end{array}$ & $\begin{array}{l}\text { Интервал частот } \\
\text { для } 0.7 \cdot \mathrm{S}_{\text {мах }}(\mathrm{f}) \\
(\text { Гц })\end{array}$ & $\begin{array}{l}\text { Резонансная } \\
\text { частота рыхлых } \\
\text { слоев (Гц) }\end{array}$ \\
\hline 1 & 2 & 3 & 4 & 5 & 6 \\
\hline \multicolumn{6}{|c|}{ Горизонтальная компонента - NS } \\
\hline 1 & 98 & 16.4 & 2.88 & $0.98-5.22$ & - \\
\hline 2 & 216 & 31.8 & 5.08 & $1.03-7.13$ & 6.64 \\
\hline 3 & 230 & 36.0 & 5.08 & $1.07-7.08$ & 5.57 \\
\hline \multicolumn{6}{|c|}{ Вертикальная компонента - Z } \\
\hline 1 & 40 & 6.84 & 2.88 & $0.98-5.22$ & - \\
\hline 2 & 84 & 11.2 & 3.27 & $0.98-7.13$ & 6.64 \\
\hline 3 & 93 & 11.4 & 2.73 & 0.98-10.79 & 5.57 \\
\hline
\end{tabular}

отложениях на участке исследования. Эти данные используются при составлении расчетных сейсмогрунтовых моделей.

Для изучаемой площади, с учетом ее относительной однородности по сейсмическим свойствам (скорости сейсмических волн и приращения балльности по двум методам, см. выше), достаточным является построение трех моделей. Модели характеризуются мощностью слоев, скоростями распространения продольных и поперечных волн и объемной массой грунтов. Для построения моделей использовались данные о скоростях распространения сейсмических волн, данные бурения скважин и данные электроразведки.

Расчет акселерограмм и их спектров проведен по методу тонкослоистых сред. Основные расчетные параметры сведены в таблице 1 [Calculation methods..., 1998].

Сами расчеты проводятся в следующей последовательности. Вначале для модели № 1 («эталон» коренных пород) окончательные результаты (максимальное ускорение) масштабируются на исходную сейсмичность, равную 7 баллам, для грунтов I категории. В итоге они для максимальной горизонтальной компоненты достигают значений $98 \mathrm{~cm} / \mathrm{c}^{2}$, максимальное значение спектра на частоте 2.88 Гц приходится на величину, равную 16.4 см/с, а интервал частот на уровне 0.7 от максимума лежит в интервале 0.98-5.22 Гц. Для вертикальной компоненты максимальное ускорение составляет $40 \mathrm{~cm} / \mathrm{c}^{2}$, максимальное значение спектра 6.84 см/с отмечается на частоте 2.88 Гц при интервале частот на уровне 0.7 от максимума 0.98-5.22 Гц.

Отмеченные значения важны для дальнейшей относительной оценки сейсмической опасности оснований проектируемых сооружений по этим же параметрам, поэтому вполне обоснованно эталонный сигнал в дальнейшем используется как исход- ный, с целью оценить возможные его изменения за счет грунтовых особенностей оснований сооружений, представленных моделями 2 и 3.

Для модели № 2, отвечающей за относительно лучшие грунтовые условия в верхней (до 14 м) зоне разреза, максимальное ускорение может дости-

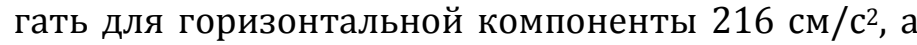

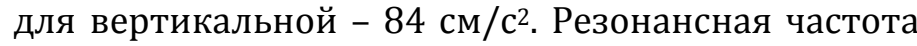
равна 6.64 Гц, а основные максимумы спектра приходятся на частоту 5.08 Гц (для горизонтальной компоненты) и 3.27 Гц (для вертикальной). Максимальное значение спектра составляет 31.8 и 11.2 см/с для NS и Z компоненты соответственно. Интервалы частот, на которых спектр ускорений превышает уровень 0.7 от максимального значения, для горизонтальной и вертикальной компонент составляют соответственно: 1.03-7.13 Гц и 0.98-7.13 Гц.

Для модели № 3, которая соответствует относительно худшим сейсмическим условиям площади, а это относительно сохранные полускальные породы с меньшими значениями скоростей в верхней зоне и увеличенными скоростями продольных и поперечных волн в переходной к скальным породам зоне, максимальные ускорения будут дости-

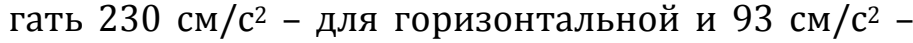
для вертикальной компоненты. Для данной модели резонансная частота составляет 5.57 Гц. Спектральная плотность достигает своего максимума на частотах 2.73 и 5.08 Гц и равна для горизонтальной компоненты 36 см/с, а для вертикальной 11.4 см/с. Частоты, на которых спектр ускорений имеет максимумы на уровне 0.7 , лежат в интервалах 1.07-7.08 Гц и 0.98-10.79 Гц - для NS и Z компонент соответственно.

Второй способ расчетов основывается на использовании экспериментальных частотных характеристик. Достоверность этого способа могла 

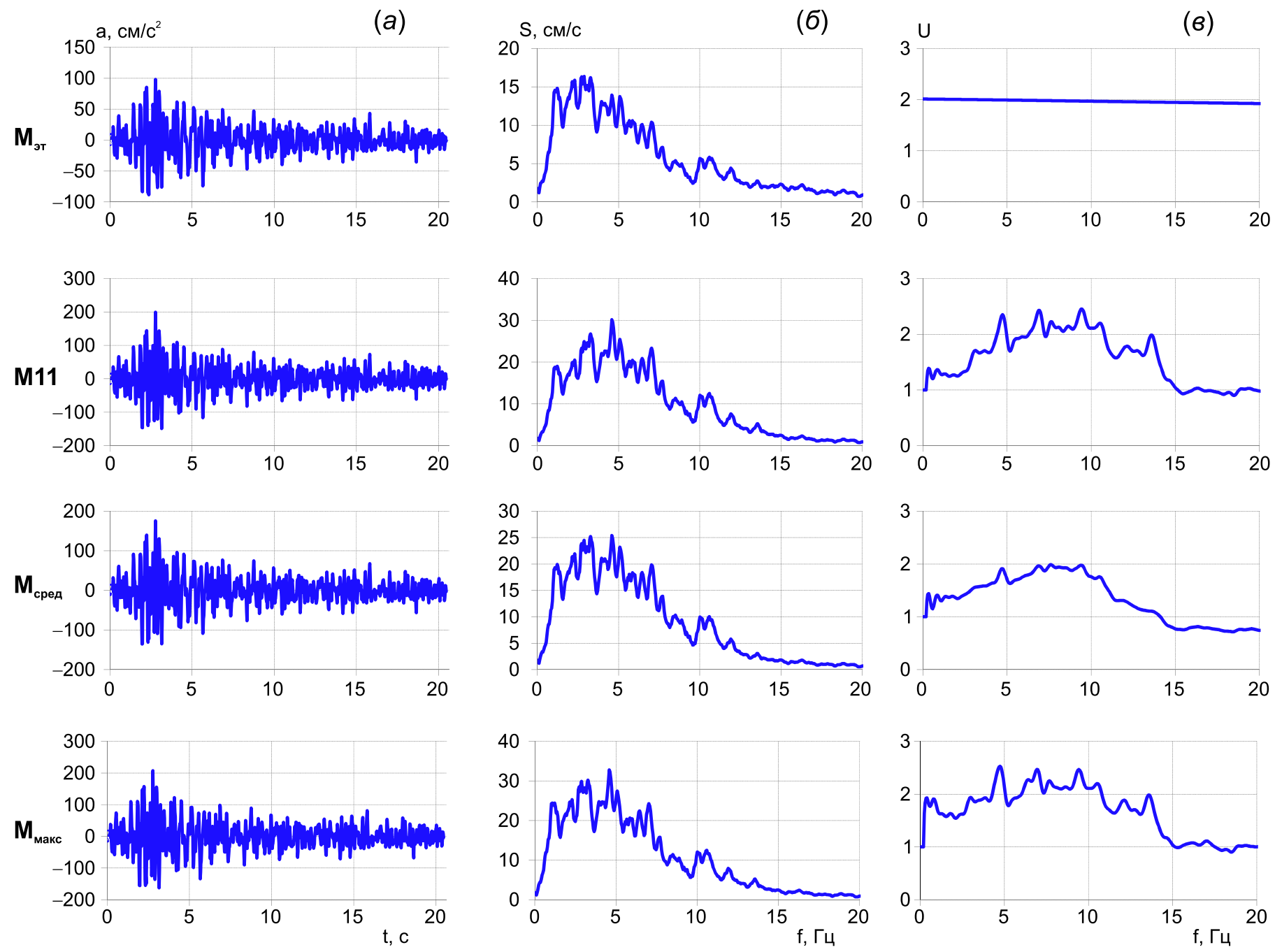

Рис. 10. Акселерограммы (a), их амплитудные спектры (б), частотные характеристики (в) для горизонтальной компоненты (слева указаны номера моделей, для которых они получены).

Fig. 10. Accelerograms (a), their amplitude spectra (б), and frequency characteristics ( 8 ) for the horizontal component (corresponding model numbers are shown on the left).

быть повышена для случая, когда частотные характеристики были бы получены для реальных относительно сильных землетрясений. В нашем случае они получены по данным микросейсм, в необходимом диапазоне частот, непосредственно на участке исследования и характеризуют сейсмические свойства грунтов на исследуемой части четвертой Ангарской террасы.

Техника расчета заключалась в умножении спектра эталонной модели $\mathbf{M}_{\text {эт }}$ (рис. 10) на выбранные частотные характеристики других моделей изучаемого участка. Были выбраны три частотные характеристики, которые по частоте и амплитуде близки к минимальным и максимальным значениям колебания для исследуемой площади. Это частотные характеристики модели М11, а также частотные характеристики, определенные для двух других моделей - $\mathbf{M}_{\text {сред и }} \mathbf{M}_{\text {макс. Сами резуль- }}$ таты расчетов представлены на рисунке 10 и в таблице 2.

Использование переходных функций, полученных по методу микросейсм (рис. 10; табл. 2), приводит к увеличению колебаний исходного сигнала верхним слоем рыхлых отложений на уровне 0.7. $\mathrm{S}_{\text {мах }}$ в основном в интервале частот исходного спектра от 1 до 7.13 Гц. Для горизонтальной компоненты максимальные ускорения лежат в пределах 176-207 см/с2. Основные максимумы частотных характеристик находятся в интервале 4-10 Гц и хорошо согласуются со значениями их максимумов, рассчитанными по методу тонкослоистых сред, которые приходятся на интервал частот $4-7$ Гц.

В общем, согласно соотношению шкал балльности и максимальных ускорений [Building Code II-7$81 *$, 2011], эти значения соответствуют 8-балльным 
A.Yu. Eskin et al.: Integrated approach to assessing the seismic hazard of urban areas...

Т а б л и ц а 2. Основные параметры расчетных акселерограмм и соответствующих им спектров

$\mathrm{T}$ a b l e 2. Main parameters of calculated accelerograms and corresponding spectra

\begin{tabular}{|c|c|c|c|c|c|}
\hline № модели & 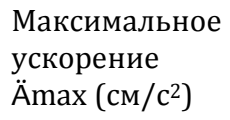 & $\begin{array}{l}\text { Максимальное } \\
\text { значение спектра } \\
\text { Smax (cм/c) }\end{array}$ & $\begin{array}{l}\text { Частота основного мак- } \\
\text { симума спектра } \\
(\text { ц) }\end{array}$ & $\begin{array}{l}\text { Интервал частот } \\
\text { для } 0.7 \cdot \mathrm{S}_{\text {мах }}(\mathrm{f}) \\
(\text { цц })\end{array}$ & $\begin{array}{l}\text { Резонансная } \\
\text { частота рыхлых } \\
\text { слоев (Гц) }\end{array}$ \\
\hline 1 & 2 & 3 & 4 & 5 & 6 \\
\hline \multicolumn{6}{|c|}{ Горизонтальная компонента - NS } \\
\hline $\mathrm{M}_{э т}$ & 98 & 16.4 & 2.88 & $0.98-5.22$ & - \\
\hline M11 & 200 & 30.2 & 4.59 & $2.69-7.13$ & 9.42 \\
\hline Мсред & 176 & 25.4 & 4.59 & $1.03-7.12$ & 7.62 \\
\hline $\mathrm{M}_{\text {макс }}$ & 207 & 32.8 & 4.59 & $1.03-7.08$ & 4.74 \\
\hline
\end{tabular}

сейсмическим воздействиям и не противоречат полученным данным.

\section{4. ЗАКЛЮЧЕНИЕ}

Проведен краткий анализ материалов по разломной тектонике, сейсмологии и сейсмогеологии района исследования. Представлена карта эпицентров местных землетрясений и карта активных разломов окрестностей исследуемой территории с установленной магнитудой будущих вероятных очагов землетрясений из зон ВОЗ.

Результаты комплексного подхода к оценке сейсмической опасности городских территорий в Южном Приангарье подтверждают высокую эффективность использованных методов при изучении сейсмической опасности исследуемого участка, расположенного в городской черте береговой зоны p. Ангары. Примененные методы и методики с успехом могут быть использованы при определении сейсмической опасности на подобных территориях региона.

Полученные результаты и сведения из опубликованных работ дают основание для принятия уточненной исходной сейсмичности района исследований, равной 8 баллам.

Расчетные величины изменений сейсмических воздействий от принятого уровня сейсмичности (8 баллов для средних грунтов) определялись местными условиями изучаемого участка и обосновываются путем использования инженерногеологических данных и постановки комплекса экспериментальных и расчетных методов сейсмического микрорайонирования. По данным экспериментальных методов получены все необходимые сведения о сейсмических параметрах эталонных и исследуемых грунтов, скоростях распространения в них сейсмических волн и распределении уровней микросейсм. Эти данные были необходимы для обоснованной оценки параметров сейсмических воздействий по методу сейсмических жесткостей и методу микросейсм. Сходимость расчетных данных хорошая, находится в пределах среднеквадратической погрешности каждого из использованных методов ( \pm 0.25 балла).

Необходимым этапом работ был прогноз сейсмических воздействий вероятных сильных землетрясений на основания сооружений. Для этого использовались расчетные методы. Для их реализации сформирован исходный сигнал (с учетом зон B03, их параметров и соответствующего местным землетрясениям спектрального состава колебаний), построено необходимое число сейсмических моделей. В результате по расчетным методам получены необходимые сведения о количественной оценке параметров движений грунта для трех сформированных грунтовых моделей на случай сильных землетрясений.

Таким образом, комплексная оценка сейсмической опасности изучаемого участка с учетом грунтовых и гидрогеологических условий, согласно СНиП II-7-81* (актуализированная редакция), по данным инструментальных методов меняется от 7.91 до 8.3 балла и принимается равной 8 баллам.

Максимальное ускорение сейсмических колебаний на случай сильных землетрясений для компоненты NS оценивается в 217-230 cм/ $\mathrm{c}^{2}$, для компоненты Z - в 84-93 см/ ${ }^{2}$, максимальные увеличения колебаний можно ожидать в интервале резонансных частот от 4 до 7-10 Гц.

\section{5. ЛИТЕРАTУРA / REFERENCES}

Building Code II-7-81* (Updated Revision), 2011. Construction in Seismic Regions. Ministry of Regional Development, Moscow, 71 p. (in Russian) [СНиП II-7-81*(Актуализированная редакция). Строительство в сейсмических районах. М.: Министерство регионального развития, 2011. 71 с.]. 
Calculation methods in construction, 1998. In: Seismic microzoning guidelines. Nauka, Moscow, p. 130-196 (in Russian) [Расчетные методы в СMP // Методическое руководство по сейсмическому микрорайонированию. М.: Наука, 1998. С. 130-196].

Drennov A.F., Dzhurik V.I., Serebrennikov S.P., Drennova N.N., 2011. Influence of the upper section on the amplitudefrequency content of a seismic signal by the example of seismic stations in the Baikal and the Transbaikal region. Seismic Instruments 47 (1), 57-65. https://doi.org/10.3103/S0747923911010099.

Dzhurik V.I., Serebrennikov S.P., Bryzhak E.V., Eskin A.Yu., 2016. To the technique of forming initial signals for predicting maximum seismic effects (case of Irkutsk). Advances in Current Natural Sciences (3), 146-152 (in Russian) [Джурик В.И., Серебренников С.П., Брыжак Е.В., Ескин А.Ю. К методике формирования исходных сигналов с целью прогноза максимальных сейсмических воздействий (на примере г. Иркутска) // Успехи современного естествознания. 2016. № 3. С. 146-152].

Electrical Exploration. Geophysicist Guidebook, 1982. Nedra, Moscow, 480 p. (in Russian) [Электроразведка. Справочник геофизика. М.: Недра, 1982. 480 с.].

Golenetsky S.I., 1997. Earthquakes in Irkutsk. Imya Publishing House, Irkutsk, 97 p. (in Russian) [Голенецкий С.И. Землетрясения в Иркутске. Иркутск: Изд-во «Имя», 1997. 97с.].

Gorbatikov A.V., Stepanova M.Y., Korablev G.E., 2008. Microseismic field affected by local geological heterogeneities and microseismic sounding of the medium. Izvestiya, Physics of the Solid Earth 44 (7), 577-592. https://doi.org/ 10.1134/S1069351308070082.

Gurvich I.I., Nomokonov V.P. (Eds.), 1981. Seismic Exploration. Geophysicist Guidebook. Nedra, Moscow, 462 p. (in Russian) [Сейсморазведка. Справочник геофизика / Ред. И.И. Гурвич, В.П. Номоконов. М.: Недра, 1981. 462 с.].

IPI2Win User Guide, 2001. MSU, Moscow, 37 p. (in Russian) [IPI2Win. Руководство пользователя. М.: МГУ, 2001. 37 c.].

Levi K.G., Masalsky O.K. (Eds.), 2005. Map of Earthquake Epicenters in East Siberia (1950-2005). Publishing House of IEC SB RAS, Irkutsk (in Russian) [Карта эпицентров землетрясений Восточной Сибири, произошедших за период 1950-2005 гг. / Ред. К.Г. Леви, О.К. Масальский. Иркутск: ИЗК СО РАН, 2005].

Logachev N.A. (Ed.), 1996. Lithosphere of Central Asia. Nauka, Novosibirsk, 238 p. (in Russian) [Литосфера Центральной Азии / Ред. Н.А. Логачев. Новосибирск: Наука, 1996. 238 с.].

Medvedev S.V., 1962. Engineering Seismology. Gosstroiizdat, Moscow, 260 p. (in Russian) [Медведев С.В. Инженерная сейсмология. М.: Госстройиздат, 1962. 260 с.].

Pavlov O.V. (Ed.), 1984. Seismic Microzonation. Nauka, Moscow, 235 p. (in Russian) [Сейсмическое микрорайонирование / Ред. О.В. Павлов. М.: Наука, 1984. 235 с.].

Pavlov O.V. (Ed.), 1988. Assessment of Soil Conditions Impact on Seismic Hazard. Guidelines for Seismic Microzonation. Nauka, Moscow, 224 p. (in Russian) [Оценка влияния грунтовых условий на сейсмическую опасность. Методическое руководство по сейсмическому микрорайонированию / Ред. О.В. Павлов. М.: Наука, 1988. 224 c.].

RSN 65-87. Engineering Surveys for Construction. Seismic Microzoning. Technical Requirements to Works, 1987. MosCTISIZ, RSFSR Gosstroi, Moscow, 26 p. (in Russian) [PCH 65-87. Инженерные изыскания для строительства. Сейсмическое микрорайонирование. Технические требования к проведению работ. М.: МосЦТИСИЗ Госстроя РСФСР, 1987. 26 с.].

RSN 66-87. Engineering Surveys for Construction. Seismic Microzoning. Technical Requirements to Geophysical Works. Seismic Exploration, 1987. MosCTISIZ, RSFSR Gosstroi, Moscow, 38 p. (in Russian) [PCH 66-87. Инженерные изыскания для строительства. Технические требования к производству геофизических работ. Сейсморазведка. Госстрой РСФСР. М.: МосЦТИСИЗ Госстроя РСФСР, 1987. 38 с.].

Seismic Microzoning Guidelines, 1988. Nauka, Moscow, 300 p. (in Russian) [Методическое руководство по сейсмическому микрорайонированию. М.: Наука, 1988. 300 с.].

The Map of General Seismic Zonation of the Russian Federation, 1999. Scale 1:8000000. The RF Ministry of Science and Technology, Schmidt UIPE, Moscow, 57 p. (in Russian) [Карта общего сейсмического районирования территории Российской Федерации. Масштаб 1:8000000. М.: Министерство науки и технологий РФ, ОИФЗ им. О.Ю. Шмидта, 1999. 57 с.].

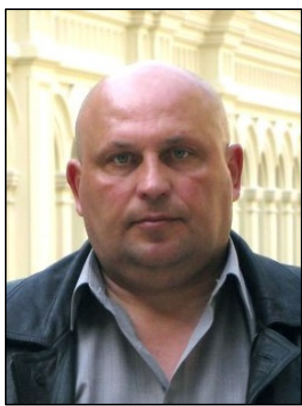

Александр Юрьевич Ескин, канд. геол.-мин. наук, н.с.

Институт земной коры СО РАН

664033, Иркутск, ул. Лермонтова, 128, Россия

凶 e-mail: eskin@crust.irk.ru

Alexander Yu. Eskin, Candidate of Geology and Mineralogy, Researcher

Institute of the Earth's Crust, Siberian Branch of RAS

128 Lermontov street, Irkutsk 664033, Russia

凶 e-mail: eskin@crust.irk.ru 

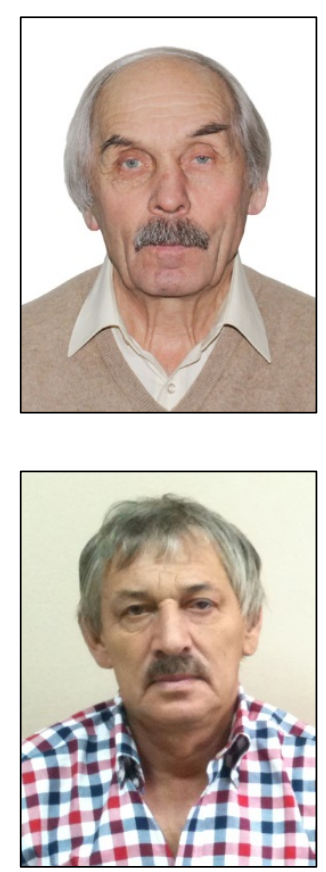

Сергей Петрович Серебренников, канд. геол.-мин. наук, с.н.с.

Институт земной коры СО РАН

664033, Иркутск, ул. Лермонтова, 128, Россия

e-mail: serebr@crust.irk.ru

Sergei P. Serebrennikov, Candidate of Geology and Mineralogy, Senior Researcher Institute of the Earth's Crust, Siberian Branch of RAS

128 Lermontov street, Irkutsk 664033, Russia

e-mail: serebr@crust.irk.ru

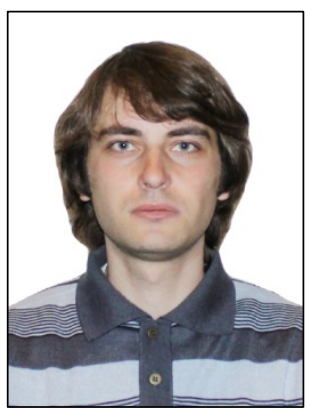

Евгений Вадимович Брыжак, канд. геол.-мин. наук, с.н.с.

Институт земной коры СО РАН

664033, Иркутск, ул. Лермонтова, 128, Россия

e-mail: bryzhak@crust.irk.ru

Evgenii V. Bryzhak, Candidate of Geology and Mineralogy, Senior Researcher Institute of the Earth's Crust, Siberian Branch of RAS

128 Lermontov street, Irkutsk 664033, Russia

e-mail: bryzhak@crust.irk.ru 